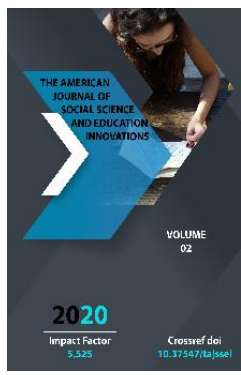

\title{
Some Morphological Characteristics Of Uzbek Dialects
}

\author{
Rakhmonov Navruz Sattorovich \\ (Phd) Navoi State Pedagogical Institute, Uzbekistan
}

Journal Website:

http://usajournalshub.c

om/index,php/tajssei

Copyright: Original

content from this work

may be used under the

terms of the creative

commons attributes

4.0 licence.

\section{ABSTRACT}

It is well known that dialects are an invaluable spiritual heritage that preserves the mental characteristics of the people. Therefore, the collection of dialect materials and their study in modern areas, along with traditional methods of linguistics and draws scientific conclusions. In Uzbek linguistics, one of the priorities is the creation of dictionaries on dialects and the creation of dialectal atlases. In this article, some morphological features of Uzbek dialects are analyzed in lingvoareal, comparative-historical and descriptive methods.

\section{KEYWORDS}

Dialect, dialectal atlas, lingvoareal, morphological form, linguistic landscape, dictionary, ethnic diversity

\section{INTRODUCTION}

In studying the current state of the dialectal linguistic landscape of Navoi region, which is the object of our research, the study of the morphological features of Uzbek dialects in the region will undoubtedly provide valuable materials to determine the linguistic nature of the grammatical structure of the Uzbek language. This is due to the fact that the region has many similarities with other Uzbek dialects in the use of morphological forms in Uzbek dialects, as well as specific features of the dialect. Such differences are due to factors such as the location of the dialect, historical conditions, ethnic diversity, population migration, as well as the influence of Uzbek dialects in the neighboring region. 
As early as the 11th century, Mahmud Kashgari noted that in Oguz and Kipchak, "for the sake of ease of pronunciation ..." some sounds were omitted in oral speech [7, 69]. It should be noted that in Uzbek dialects, too, the principles of simplicity and economy apply to the combination of certain adjectives and words, as required by ease of pronunciation.

\section{MATERIALS AND METHODS}

Odamla (Odamlar- in literary language) meaning: people, biza // bizar (Bizlar- in literary language) meaning: we, kitabiz (Kitobingiz- in literary language) meaning: your book, uyinsqa boring (uyingizga boring- in literary language) meaning: go home, ke: ng (Kelingin literary language) meaning: come, welcome, o: ng (oling- in literary language) meaning: take, help yourself. It should be noted that Navoi region has similarities with other Uzbek dialects in the use of Uzbek dialects, as well as other Uzbek dialects, but at the same time as a product of a long historical process, the dialects developed against the background of external and internal influences. The Uzbek and Kazakh peoples have long lived side by side in the Navoi region, and in some areas mixed. This does not go unnoticed in this or that language. Including Kyzylcha of Nurata district; In the dialects of Shurtepa and Kenagas villages of Konimex district, Uzbeks living mixed with Kazakhs have plural forms [-dar // -der, -tar // tar]. Variants of the plural form [-dar // -der] are also found in the dialects of Yangikurgan district of Namangan region and Sherabad district of Surkhandarya region. The -dar // dar, -tar // -tar forms of the plural are also available in Kazakh, Kyrgyz, Bashkir, Tuva, and Altaic languages [14, 16]. The use of the suffix (') instead of the suffix - (i) in the second person plural literary language is a typical phenomenon for the Qarluq and mixed Uzbek dialects of the region. The transition of ng to $y$ between two vowels may have changed from - (') ng'z as a result of [ng> y]: [- (') hundred <(') ng'z]; otəngz> otəyz, koz'ngz> koz'i'z> koz': $z>$ koz'z [12, 146]. In general, the second person plural - (') face form is typical of Qarluq-type Uzbek dialects and is also found in Osh, Uzgen, Jalal-Abad, Namangan, Lower Kashkadarya, Kattakurgan, Tashkent, Jizzakh dialects. The peculiarity of this fact is that in the Kipchak-type dialects of the region, such as Oltinsoy, Xonaqa, Kuksaroy, Dorman, as a result of the influence of Qarluq-type dialects, the (-) face form is actively used.

In the bilingual (Uzbek-Tajik) Kyzyltepa, Nurata, Ghazgan dialects of Navoi region, there are variants of the possessive suffix um, -ung: oglum, oglung, bogum, bogung, chirogum, chirogung. This variant of the possessive suffix is also found in the bilingual dialects of the neighboring Bukhara region [9, 46]. In regional dialects, as a result of the addition of possessive suffixes, there are also sound-changing phenomena such as [q> $g^{\prime}, k>$ g, p> v]: taragim, 'staghm, kel' sov' (keli dastasi), gav'ng (gaping). The area under study is four indicators of the six conventions in the snow-type dialects, in which the contraction and fall contractions do not differ. Direction and place-time agreements are also applied in a mixed manner. It occurs mainly in Navoi, Samarkand, Bukhara, Karshi dialects. Although the indicators of these agreements are the same, but each of them is an independent agreement. Because they differ in their application, functions, semantic features. The - $ə$ // -a form of the consonant is used in the Karmana, Hazara, and Qiziltepa dialects of the Qarluq type as part of the 
words she: ra, o: ra, be: ra. It is known from the dialectological literature that this form is the main morphological indicator of the dialects belonging to the Oghuz dialect. In the dialects under study, this form also appeared as a result of the influence of the Bukhara Oghuz type dialects. Comparison: Karakul: she: ra, o: ra, be: ra; Khorezm: be: ra, shö: ra, hö: ra $[9,65 ; 1,173]$.

The -ye form of the directional agreement is found in the Karmana, Hazara, and Kyzyltepa dialects of the Qarluq type. This suffix is added to words ending in a vowel: hovl'ye, kochaye, Buxoroye. Comparison: In Kattakurgan:'ch'ye, oz'ye; hovliye (yard) in Tashkent.

In Choya, Qizilcha, Qumrabod, Langar dialects of Navoi region, the form of the verb $-n$, -in, which was used in Turkic languages until the XV century, has been preserved [3, 32; 4, 5961]: Erten ketemiz // Erta bilan ketamiz.( We leave tomorrow // We leave early; Kunun ishladi // Kuni bilan ishladi (He worked the day // He worked the day); Tunun uhlmad // Tuni bilan uhlamadi (He didn't sleep last night // He didn't sleep at night). In these dialects, the word tomorrow is also used in the sense of tomorrow. In Soykechar dialect Erten op kep beraman (Ertaga olib kelib beraman) : I'll give it to you tomorrow (I'll bring it tomorrow).

It is noteworthy that in the dialects of the study area, including Uyrot, Bahrin of Karmana district; In the Iranian dialects of Khatirchi district, Tortuvli rural dialects, the (- i) mtir // (i) mtil forms of the reduced degree are also found in addition to the bitter quality, which expresses the meaning of taste: achqimtil (more bitter).

In the dialects of Baroq, Oqqula, Yangiabad villages of Nurata district [ene/mene], [-kəy, - key] is used by adding suffixes to the question pronouns and the meaning of the accent is expressed: as in ənakəy, mənəkəy, qanikey (where?). This situation is also observed in Karshi, Parkent and Samarkand dialects.

\section{RESULTS AND DISCUSSIONS}

In order to emphasize the meaning of the command-desire, the -gay form can sometimes be added in Kipchak-type dialects: boragay, kelagay. Comparison: boragay - bora qol (stay - go), Kelagay - kela qol (stay come);

In the regional dialects, the second person plural form of the imperative mood

It is formed by the suffixes [- (') ng / - (y) ng / yngiz / -yng'ys / -yngyz] and its meaning is directed to the plural, the general (except the meaning of respect): ayting, ket'ng, o: ng, ke: ng, ko'ringiz, aytingiz, tushingiz. The -lar form may also be added after these additions. In this case, sometimes there is a phenomenon of narrowing of the verb structure $[12,129]$ with the requirement of maximum simplification of pronunciation in oral speech: bor'zlə, ગl'zlə (-'zlə> -ingizlar). The second person plural forms also differ semantically. Comparison: in Kipchak dialects: ke: ngner (command, suggestion in relation to the general); kelzle // kel'ngzle (command, suggestion to an elderly or respected person).

Inter-dialectal variation of a morphological form in Uzbek dialects, the occurrence of which in different phonetic forms is associated with a number of ethnolinguistic factors. Morphological variability has also emerged in the studied dialects as a result of the interaction of the elements karluq, kipchak, and in part Oguz. The analytic - (i) b edi form of the past tense has a different 
appearance in the dialects under study. In the dialects of Kadak, Qirhovud, Qizilhovud, Nogora, Hasanota, Anna, Tutli, Tikanli, Soykechar villages of Nurata district, which belong to the Kipchak dialect, the past tense verb form - (i) b edi is used in the form of (i) ved: ket'ved', ayt'edim, barvi: Indigenous people - (i) vedi-used by Turkmens and the areas where they live are called Jagalov (indicating that they are located on the edge of a mountain). There are also records that the so-called Nurata Turkmen ethnos spread to the territory of Jizzakh, Samarkand and Navoi regions [9, 33]. This form is also present in the dialects of Sarigul, Toz, Aymat, Mijgan, Jonbulak, Boronbulak villages of Koshrabat district of Samarkand region. Comparison. Khorezm (Kipchak): bar'vi: d'm, bar'vi: d'ng, bar'vi: d', bar'vi: d'k, bar'vi: d'ngler, bar'vi: $\mathrm{d}^{\prime}($ ler) [2, 165]; In the Uzbek dialects of Tajikistan: bor'ved'm [6, 25]. -ib ed form Choya, Jarma, which is adjacent to the area; Occurs in the dialects of Sayyod, Toroma, Crimea, Kazakh villages of Khatirchi district: as if I went and told. This form is also found in the Turkestan group Qarluq-Kipchak [10, 122], Upper Kashkadarya Kipchak-type Uzbek dialects [5, 24]. In the Qarluq, Kipchak, and mixed dialects of the study area, the -uvdi form is widely used: boruvdim, aytuvding, uvluvdi. This form is mainly characteristic of all Uzbek dialects of the Qarluq type, and represents the meaning of an action performed in the distant past.

The past tense verb - (a) $r$ edi is also found in the dialects of the villages of Karmana and Kyzyltepa districts of Navoi region - (a) sdi: borasd'm, (went, )aytasd'ng,(told) b'lasd (was/were)'.
It is characteristic that in the dialects of Uchtut and Kuksaroy villages there is an enlarged form "borayatuvdim" of the future tense. Endi siznikiga borayturudim (Endi siznikiga bormoqchi bolib turgandim) (I was going to yours);

In Kipchak-type dialects, including the dialects of Eski and Chashma villages of Nurata district, the auxiliary verb yatdi is used in the Uzbek literary language to mean the auxiliary verb yuribdi: Boleler enasinkiga kebketb janitt. In literary language: The children come and go to their mother's house. In the dialects of Eski, Chashma, Samari, Ajrim villages of Nurata district, the auxiliary verb to send in the literary language occurs in the form of a jar under the influence of Qarluq type dialects: Suvdy ichibjar (drink water). In compare aytvordi, olivordi, in Qarluq dialect.

In the regional dialects, the -kar, -kir forms are used in parallel with the -kaz, -kiz forms in the Uzbek literary language. The analysis of dialectal materials collected from regional dialects shows that such forms are more widely used, mainly in the dialects of mixed and mixed types: o'zkazmoq // o'rtaqmoq (pass), ketkizmoq // ketkirmoq(leave,) itkazmoq // bitkarmoq (finish). The -kar // -kir forms of the accusative pronoun are widely used in the written sources of the old Uzbek literary language, including Navoi's works: ... These two people lost their lives... Verbs in the accusative pronoun in the Uzbek literary language such as aqizmoq (flow,)tomizmoq (drip), emizmoq (soak).

The -maslik suffix, which forms the infinitive form of the noun, is mainly used in the Qarluqtype (sometimes Kipchak-type) dialects of the region, while the -mash form is widely used in Kipchak and mixed-type dialects. -mash form 
in Kipchak-type dialects, including Soykechar, Choya, Jarma, Barak of Nurata district; Chagatoy, Uchkara, Tasmachi, Kuksaroy, Yangikishlak, Chechakota, Dovtepa of Khatirchi district; Yangikurgan, ljand, Navruz, Kalkanota, Burkut of mixed type of Navbahor district; Widespread in Shurtepa, Jambul rural dialects of Konimex district. The expression of indivisibility with the help of the affix -ma, formed by the affix - (i) sh, is found in the Khorezm and Andijan dialects of modern Uzbek (yozish- yozmash, bilish - bilmash) (writing - not writing, knowing - not knowing) and in the language of Uyghurs living in Almaty region.

\section{CONCLUSION}

The analysis of linguistic evidence collected as a result of the research showed that Uzbek dialects retain many phonetic, lexical and morphological features of the language. Each dialect has to some extent unique morphological features. However, there are aspects of the same features that belong to a particular dialect that are common to all dialects, which can be explained by factors such as the historical context of the regions, the influence of sibling and non-sibling languages. This is fully confirmed by the materials of Uzbek dialects of Navoi region which is the object of research.

\section{REFERENCES}

1. Abdullaev F.F. Khorezm dialects of the Uzbek language. -T., 1969.

2. Abdullaev F. Oghuz dialect of the Uzbek language. - Tashkent, 1978.

3. Abdurahmonov G., Rustamov A. Ancient Turkic language., -T., 1982.
4. Abdurahmonov G., Shukurov Sh. Historical grammar of the Uzbek language., - T., 1973.

5. Juraev B. Upper Kashkadarya Uzbek dialects. -T .: Science, 1969.

6. Yuldashev T. Uzbek dialects in Tajikistan. -T. 1986.

7. Kashgari Mahmud. Devonian dictionary is Turkish. -T., Volume I, 1960.

8. Mirzaev M. Bukhara group dialects of Uzbek language. -T .: Fan, 1969.

9. Muhammadjonov Q. Morphology of Uzbek dialects in South Kazakhstan. -T. 1983.

10. Reshetov V.V. , Shoabdurahmonov Sh. Uzbek dialectology. -T .: Fan, 1978.

11. Sanaqulov U., Suvonqulov I. Ethnology (tree) of the Oghuz component of the Uzbek people and language. Samarkand, 2013.

12. Nigora $M$. The historical development of the language-the basis of human history //International Journal on Integrated Education. - 2019. - T. 2. - №. 4. - p. 119121.

13. Jumayevna Y. N. Linguo culture logical features of metaphors in children's literature (On the example of khudayberdi tokhtabayev's creative work) //ACADEMICIA: An International Multidisciplinary Research Journal. 2019. - T. 9. - №. 4. - p. 139-145.

14. Norboyevna Y. R. Structural-semantic, national-cultural features of words in uzbek language //Asian Journal of Multidimensional Research (AJMR). 2020. - T. 9. - №. 5. - p. 409-414. 